MARIA DĘBOWSKA* - LUBLIN

\title{
ARCHIWA KOŚCIOLA KATOLICKIEGO W II RZECZYPOSPOLITEJ
}

Według Z. Mamczak-Gadkowskiej, okres Polski międzywojennej ,uznawany jest powszechnie za niezwykleważny dla dalszego rozwoju archiwów polskich i polskiej archiwistyki"'. To stwierdzenie odnosi się również do archiwów kościelnych ze względu na to, że w tym czasie rozpoczął się proces wypracowywania nowoczesnych form ich funkcjonowania. Na określenie tego procesu znany archiwista przemyski ks. Jan Kwolek używał określenia: naukowa organizacja archiwów. Archiwa kościelne zaczęto postrzegać jako instytucje naukowe oraz warsztat pracy dla historyków ${ }^{2}$. Takie funkcje mogły one pełnić dopiero po reorganizacji istniejących wówczas w instytucjach kościelnych archiwów - czy raczej registratur (składnic akt). Na lata II Rzeczypospolitej przypadają początki tworzenia kościelnych archiwów historycznych jako samoistnych instytucji. Proces przemian dokonywał się we współpracy duchownych i świeckich archiwistów oraz historyków.

Terminu ,archiwum historyczne” można użyć na określenie wyspecjalizowanej instytucji powołanej do zabezpieczania, gromadzenia, opracowywania oraz trwałego przechowywania i udostępniania materiałów archiwalnych. W polskim

\footnotetext{
*Maria Dębowska - dr hab. historii, adiunkt w Instytucie Archiwów, Bibliotek i Muzeów Kościelnych KUL.

${ }^{1}$ I. Mamczak-Gadkowska, Archiwa państwowe w II Rzeczypospolitej, Poznań 2006, s. 7.

${ }^{2}$ Zarówno podczas zjazdów historyków, jak i Związku Zakładów Teologicznych przedmiotem obrad czyniono badania nad historią Kościoła w Polsce oraz jej nauczaniem w seminariach duchownych. W dyskusjach i wnioskach zwracano uwagę na kwestie wiążące się z teorią i praktyką archiwalna. Zalecano wprowadzenie archiwistyki do ratio studiorum w seminariach duchownych, ustanowienie w każdej kurii diecezjalnej urzędu archiwisty, porządkowanie i sporządzanie inwentarzy materiałów archiwalnych, przejmowanie do archiwum diecezjalnego najstarszych akt z archiwów parafialnych, publikowanie instrukcji, zob. Pamiętnik Czwartego Zjazdu w Kielcach 20 IV - 22 IV 1927 roku, Kielce 1927, s. 178; Pamiętnik IV Powszechnego Zjazdu Historyków Polskich w Poznaniu 6-8 grudnia 1925, t. 2: Protokoły, wyd. K. Tyszkowski, Lwów 1927, s. 105; J. Umiński, Uchwaty IV Zjazdu Historyków Polskich w Poznaniu, „Miesięcznik Pasterski Płocki”, 21 (1926) nr 12, s. 451.
} 
prawie archiwalnym takiego pojęcia nie było. Nie umieszczono go w słowniku archiwalnym ${ }^{3}$. W obecnie przygotowywanej, nowej ustawie archiwalnej takie określenie najprawdopodobniej się znajdzie $e^{4}$. Jeden z teoretyków archiwistyki, Bohdan Ryszewski pojęciem „,archiwum historyczne” określa zespół, grupę zespołów lub zbiór powstały jako wytwór działalności instytucji już nieistniejącej. Zaproponował wprowadzenie archiwum historycznego jako jednego z elementów w strukturze zasobu archiwów ${ }^{5}$.

W prawie kościelnym pojęcie archiwum historycznego, jako instytucji gromadzącej materiały archiwalne niepotrzebne do bieżącego funkcjonowania kancelarii kościelnych, pojawiło się dopiero w Kodeksie Prawa Kanonicznego z 1983 roku. Niektórzy badacze twierdzą, że w KPK z 1917 roku jest już mowa o nowoczesnych archiwach diecezjalnych ${ }^{6}$. Jest to interpretacja zbyt daleko idąca, gdyż w rzeczywistości ustawodawca kościelny zapisał jedynie konieczność stworzenia w każdej kurii diecezjalnej dwóch archiwów - zwykłego (czyli archiwum kurii diecezjalnej, będącego w rzeczywistości składnicą akt) i tajnego. Archiwum nazwane przez ustawodawcę ,zwykłym” jest uważane przez niektórych za instytucję, o której mowa. Do takiego interpretowania zapisu w KPK mógł przyczynić się następujący zapis: „W archiwum zwykłym przechowuje się starannie wszelkie dokumenty odnoszące się do spraw diecezji tak duchownych, jak doczesnych"”. Niepoprawności takiego myślenia dowodzi kolejny zapis, a mianowicie - „Archiwum powinno być stale zamknięte, a klucz ma być u kanclerza. Biskup tylko lub wikariusz generalny oraz kanclerz mogą pozwolić na wejście do archiwum (kan. 377)"'. Taki zapis nie jest w pełni zgodny z pojmowaniem archiwum jako instytucji naukowej, jako warsztatu pracy dostępnego dla historyków ${ }^{9}$. Zapis w nowym Kodeksie Prawa Kanonicznego o utworzeniu w każdej diecezji historycznego archiwum diecezjalnego jest nowością jedynie w prawie kościelnym, gdyż w praktyce niektóre diecezje w Polsce takie archiwa erygowały już w latach międzywojennych.

Brakuje opracowania poświęconego początkom organizowania $\mathrm{w}$ okresie międzywojennym kościelnych archiwów historycznych. Archiwiści kościelni po drugiej wojnie światowej obficie czerpali z tego, co już zrobiono w okresie mię-

${ }^{3}$ Zob. Polski stownik archiwalny, red. W. Maciejewska, Warszawa 1974.

${ }^{4}$ Termin ,archiwum historyczne” znalazł się w projekcie nowej ustawy archiwalnej.

${ }^{5}$ B. Ryszewski, Problemy komputeryzacji archiwów, Toruń 1994, s. 20.

${ }^{6}$ Zob. F. Lenort, Z dziejów organizacji i zasobu Archiwum Archidiecezjalnego w Poznaniu, „Archiwa, Biblioteki i Muzea Kościelne” (dalej: ABMK), 15 (1967) s. 28-30; H. Robótka, B. Ryszewski, A. Tomczak, Archiwistyka, Warszawa 1989, s. 386.

${ }^{7}$ F. Bączkowicz, Prawo kanoniczne. Podręcznik dla duchowieństwa, t. 1, Opole 1957, s. 534.

${ }^{8}$ Tamże, s. 535.

${ }^{9} \mathrm{~W}$ związku z tym zapisem w KPK warto zwrócić uwagę na pewien znamienny przykład. Podczas IV Zjazdu Zakładów Teologicznych (Kielce, 1927 r.), po dyskusji nad referatem M. Skibniewskiego TJ (O warunkach pracy nad historią Kościoła), wygłoszonym w ramach Sekcji Historii Kościoła, podjęto m.in. następującą uchwałę: ,prosić Księży Biskupów o pozwolenie i ułatwienie odpowiednich badań w archiwach diecezjalnych”. Wspomniane badania miały dotyczyć udziału duchowieństwa w powstaniu listopadowym, zob. Pamiętnik Czwartego Zjazdu w Kielcach $20 \mathrm{IV}$ 22 IV 1927 roku, s. 178. 
dzywojennym ${ }^{10}$. Mimo tego, początki organizowania nowoczesnych archiwów kościelnych nie cieszyły się ich zainteresowaniem na tyle, by podjąć trud pokazania znaczenia tego okresu dla rozwoju polskich archiwów kościelnych po drugiej wojnie światowej. Poza artykułami programowymi, które zostały opublikowane przed wojną, w okresie powojennym praktycznie nie powstało opracowanie ukazujące znaczenie tego okresu w rozwoju historycznych archiwów kościelnych w Polsce. Czołowi archiwiści kościelni (S. Librowski, H. E. Wyczawski) zasygnalizowali jedynie działania podejmowane przez przedwojenną kościelną służbę archiwalną w ramach porządkowania zbiorów kościelnych i organizowania nowoczesnych archiwów ${ }^{11}$. Odniesienia do tej kwestii można odnaleźć u badaczy dziejów tych archiwów kościelnych, które zostały erygowane w okresie międzywojennym. Proces powstawania nowoczesnych archiwów kościelnych odnotowali także autorzy opracowania Archiwistyka ${ }^{12}$. Zauważyła to zagadnienie także Irena Mamczak-Gadkowska w pracy poświęconej archiwom państwowym w II Rzeczypospolitej ${ }^{13}$.

Początki powstawania archiwów zwanych nowożytnymi lub nowoczesnymi przypadają na koniec XVIII wieku oraz wiek XIX. Prekursorem przemian była Francja, gdzie już pod koniec XVIII wieku rozpoczął się ten proces. $Z$ niej wiele krajów czerpało wzorce do naśladowania. Co było istota przemian? U podstaw reorganizacji archiwów leżały zmiany polityczne (we Francji upadek monarchii i konieczność archiwizacji akt wytworzonych przed rewolucją) oraz niemożność wchłonięcia przez archiwa bieżące całej historycznej i narastającej dokumentacji. To zmuszało do szukania i stosowania innych rozwiązań organizacyjnych. Nastąpiło ostateczne odłączenie się archiwów historycznych od archiwów bieżących i nadanie tym pierwszym statusu samodzielnych komórek w ramach poszczególnych instytucji. Wówczas także powstawały archiwa jako jednostki samodzielne organizacyjnie. Nowoczesne archiwa historyczne stały się wyspecjalizowanymi instytucjami, które ułatwiały badania stając się warsztatami pracy naukowej. Nie były to już składnice akt albo inaczej rzecz ujmując magazyny akt, w których dbano głównie o to, by materiały archiwalne były wystarczająco chronione. Powstające archiwa historyczne organizowano w sieci zdecentralizowane lub scentralizowane. Pierwsza sieć archiwów powstała we Francji, następnie w Prusach - od 1831 roku pod zarządem centralnym; potem w Belgii i Holandii, kolejna w państwach włoskich - od 1874 roku z centralnym zarządem. W tym samym

${ }^{10}$ Jednym z nich jest Stanisław Librowski, autor opracowań: Stan i potrzeby archiwów kościelnych oraz program pracy na najbliższy okres, ABMK, 1 (1959/1960) z. 1, s. 20-33, Dotychczasowe osiagnięcia $w$ dziedzinie reformy organizacji archiwów kościelnych $w$ Polsce, ABMK, 3 (1961) z. 1-2, s. 3-24.

${ }^{11}$ Librowski, Dotychczasowe osiagnięcia, s. 11-16; H. E. Wyczawski, Polskie archiwa kościelne, w: Księga tysiaclecia katolicyzmu w Polsce, cz. 2, Lublin 1969, s. 91-92; tenże, Przygotowanie do studiów w archiwach kościelnych, Kalwaria Zebrzydowska 1989, s. 330.

${ }^{12}$ Robótka, Ryszewski, Tomczak, Archiwistyka, s. 386-388.

${ }^{13}$ Mamczak-Gadkowska, Archiwa państwowe w II Rzeczypospolitej, s. 245-246. 
czasie powstawały zdecentralizowane sieci archiwów w Anglii, Austrii, Hiszpanii i Rosji ${ }^{14}$.

W wyniku rozbiorów Polski zamknięto wiele urzędów i instytucji polskich okresu przedrozbiorowego, co stało się powodem masowej archiwizacji akt. Powstały pierwsze archiwa historyczne gromadzące materiały archiwalne wytworzone w okresie staropolskim (np. Archiwum Ogólne Krajowe w Warszawie). Archiwa historyczne z czasem gromadziły także dokumentację wytworzoną w XIX stuleciu, która niekiedy przewyższała zasób z okresu staropolskiego. Polskie archiwa historyczne dopiero po odzyskaniu przez Polskę niepodległości mogły zacząć nadrabiać zaległości z okresu zaborów. Na początku lat dwudziestych istniała sieć państwowych archiwów historycznych, która obejmowała dwadzieścia jeden instytucji zarządzanych przez ówczesne naczelne władze archiwalne - Wydział Archiwów Państwowych, podlegający Ministrowi Wyznań Religijnych i Oświecenia Publicznego ${ }^{15}$.

Reorganizacja oraz likwidacja kościelnych instytucji i urzędów w okresie zaborów wiązała się także z koniecznością archiwizacji akt wytworzonych w okresie przedrozbiorowym. Wówczas nie stało się to jednak impulsem do tworzenia odrębnych kościelnych archiwów historycznych. Akta znoszonych urzędów, instytucji wędrowały przeważnie do innych instytucji kościelnych, gdzie zalegały w składnicach akt. Rzadko docierali do nich historycy. Dopiero w latach międzywojennych sytuacja dojrzała do tego, by dokonać zasadniczych reform. Chęć zmian oddają najlepiej słowa ks. Jana Kwolka z Przemyśla: „w odrodzonej Ojczyźnie pragniemy mieć także odrodzone archiwa kościelne, pragniemy ich uporządkowania i ożywienia w nich ruchu naukowego dla dobra Kościoła i Ojczyzny" ${ }^{16}$. Wagę dzieła reformy archiwów kościelnych podkreślił Kazimierz Konarski, autor pierwszego polskiego podręcznika z archiwistyki ${ }^{17}$ : ,,ma to duże znaczenie dla Kościoła, któremu akcja ta ułatwi uporządkowanie i należyte ocenienie ogromnego działu jego bogactw, ma niemniejsze znaczenie i dla archiwistyki świeckiej, ile że prowadzi do stworzenia w kraju gęstej sieci placówek opieki nad archiwaliami, co z kolei nie może nie oddziałać dodatnio na podniesienie się ogólnej kultury archiwalnej w Polsce"18.

Sprawę podniesienia poziomu nauczania historii Kościoła podejmowano na Zjazdach Związku Zakładów Teologicznych w Polsce (Łomża, Kielce). W kręgach kościelnych jednak nie zawsze widziano potrzebę organizowania archiwów jako warsztatów badań naukowych. Nie wszyscy uświadamiali sobie wpływ dobrze działającego nowoczesnego archiwum na poziom badań naukowych. Wiele

${ }^{14}$ S. Pańków, Archiwa, Warszawa 1975, s. 40-43; Robótka, Ryszewski, Tomczak, Archiwistyka, s. $252-259$.

${ }^{15}$ A. Tomczak, Zarys dziejów archiwów polskich. Część I - do wybuchu I wojny światowej, Toruń 1974, s. 91-133.

${ }^{16}$ J. Kwolek, Archiwa - przeszłości skarbnice, „Ateneum Kapłańskie” (dalej: AK), 21 (1935) t. 36 , s. 528 .

${ }^{17}$ K. Konarski, Nowożytna archiwistyka polska i jej zadania, Warszawa 1929.

${ }^{18}$ K. Konarski, Z archiwistyki kościelnej. Ateneum Kapłańskie, „Archeion”, 15 (1937-1939) s. 127. 
zależało od poszczególnych ordynariuszy, którym były podporządkowane zbiory archiwalne na terenie diecezji przez nich zarządzanych. Pozyskanie hierarchii kościelnej dla idei szerszego otwarcia archiwów i udostępnienia materiałów archiwalnych do celów naukowych nie było łatwe nie tylko ze względów finansowych. Zwrócił na to uwagę Józef Siemieński. W trakcie dyskusji po referacie K. Kaczmarczyka podczas zjazdu historyków w Poznaniu w 1925 r., stwierdził: ,jesteśmy [...] w czasach szczególnie niepomyślnych. Kościół do niedawna musiał znosić ograniczenia krzywdzące, musiał znosić deptanie prawa kanonicznego przez zaborców. Obecnie czynniki kościelne popadają w reakcję, dążą do maksimum praw. Nadto możliwość dojścia do władzy kierunków radykalnych napełnia je obawą przed ingerencją państwa w sprawy kościelne. Stąd przedrażliwość na punkcie immunitetu kościelnego"19. Ksiądz Henryk Likowski w dyskusji na IV Zjeździe Historyków zauważył, że ,z kołami duchownymi najlepiej przyjdzie do porozumienia w sprawie archiwów nie drogą oficjalnych konferencji, lecz raczej drogą wymiany myśli z poszczególnymi Ks.Ks. Biskupami, zwłaszcza, jeśli można ofiarować subwencje na uporządkowanie archiwów kościelnych i jeśli się z góry zrezygnuje z jakiegokolwiek nadzoru nad nimi”"20. Ksiądz Jan Kwolek, archiwariusz z Przemyśla szukał zrozumienia również u kapłanów zatrudnionych w kuriach diecezjalnych - ,po licznych dotąd, a nie bezowocnych apelach do Biskupów, trzeba dziś nawoływania kierować raczej do kapłanów, którzy z racji swego wykształcenia i stanowiska przy biskupim dworze, najwięcej są powołani do pracy organizacyjnej $\mathrm{w}$ archiwach diecezjalnych, pod protektoratem oczywiście swoich dostojnych Arcypasterzy" ${ }^{21}$. Sprawę podniesioną przez Kazimierza Kaczmarczyka podjął właśnie on. Wśród duchownych stał się on najbardziej energicznym propagatorem idei organizowania nowoczesnych archiwów kościelnych. Jego programowy artykuł pod tytułem Naukowa organizacja archiwów diecezjalnych został opublikowany w „Archeionie”22. Ten sam artykuł (rozszerzony) pod tytułem Naukowa organizacja archiwów kościelnych został przedrukowany jeszcze w dwóch czasopismach - „Nasza myśl Teologiczna” i „Przegląd Teologiczny"23.

W artykule tym ks. Kwolek podał warunki powstania nowoczesnego archiwum kościelnego:

- właściwy osoba czyli organizator

- pomieszczenie (magazyn, pracownia)

- zaprowadzenie ogólnego porządku w zasobie

- szczegółowa inwentaryzacja

- propagowanie idei opieki nad materiałami archiwalnymi wśród kleru diecezjalnego

- koncentracja mniejszych archiwów w archiwum diecezjalnym

${ }^{19}$ Pamiętnik IV Powszechnego Zjazdu Historyków Polskich, t. 2, s. 141.

${ }^{20}$ Tamże, s. 142.

${ }^{21}$ J. Kwolek, Naukowa organizacja archiwów diecezjalnych, „Archeion”, 4 (1928) s. 20.

${ }^{22}$ Tamże, s. 15-35.

${ }^{23}$ J. Kwolek, Naukowa organizacja archiwów kościelnych, „Nasza Myśl Teologiczna”, 1930, s. 113-149; „Przegląd Teologiczny”, 11 (1930) s. 15-35. 
- organizacja prawna, czyli statuty i regulaminy.

Mając świadomość ogromnej wartości materiałów archiwalnych przechowywanych w różnych archiwach kościelnych dla badania przeszłości narodu polskiego, historycy czynili starania, aby równolegle z rozwojem archiwów państwowych dokonywana była także reorganizacja archiwów kościelnych. Bez powołania do życia samodzielnych instytucji kościelnych, dzięki którym udostępniano by do badań naukowych kościelne materiały archiwalne, trudno byłoby marzyć o w miarę swobodnym z nich korzystaniu. Takiej możliwości nie było, dopóki dokumentacja pozostawała w składnicach kurii diecezjalnych, za które odpowiedzialni byli specjalnie do tego celu powoływani archiwariusze24 lub w przypadkach braku takowych - kanclerze kurii25. Porządkowanie i inwentaryzacja akt w składnicach kurii nie była prowadzona w celu udostępniania ich do badań naukowych, chociaż nie zamykano szczelnie archiwów kurii diecezjalnych przed badaczami26.

Prawdopodobnie pierwszym głosem historyków w sprawie reorganizacji archiwów kościelnych stał się II Powszechny Zjazd Historyków Polskich, który odbył się we Lwowie w 1890 roku. Wówczas to, na wniosek Stanisława Krzyżanowskiego, zwrócono się do władz diecezjalnych i zakonnych w sprawie zakładania i popierania archiwów, bibliotek i muzeów kościelnych ${ }^{27}$. Poza pojedynczymi inicjatywami, większego odzewu nie było.

Dyskusję dotyczącą reformy archiwów kościelnych w Polsce międzywojennej rozpoczął Kazimierz Kaczmarczyk, dyrektor Archiwum Państwowego w Poznaniu. Okazją do tego stał się IV Powszechny Zjazd Historyków Polskich w Poznaniu w 1925 roku (6-8 XII). Kaczmarczyk wygłosił na nim referat pod tytułem Organizowanie archiwów diecezjalnych ${ }^{28}$. Referat ten w nieco krótszej formie $(W$ sprawie archiwów diecezjalnych) ogłosił w dwa lata później w organie urzędo-

${ }^{24}$ W strukturze Kurii Diecezjalnej w Łucku na Wołyniu została utworzona w 1926 r. Sekcja Statystyczna (w następnych latach przekształcona w Sekcję Statystyczno-Archiwalną), której przewodniczył ks. Florentyn Czyżewski. Do zadań pracowników tej sekcji należało sporządzanie wykazów statystycznych, opieka nad aktami metrykalnymi, troska o archiwa parafii i różnych instytucji diecezjalnych. Ks. Florentyn Czyżewski pracował nad materiałami archiwalnymi pozostającymi w tamtejszej składnicy akt. M.in. sporządził rozbudowane indeksy do wielu ksiag metrykalnych. Poczynił także z nich rozmaite wypisy, zob. M. Dębowska, Organizacja Kurii Biskupiej w Lucku. Studium kancelaryjno-archiwoznawcze, ABMK, 71 (1999) s. 391.

${ }^{25}$ Głównym zadaniem kanclerza kurii diecezjalnej ,jest strzec złożonych w archiwum akt kurii, chronologicznie je porządkować i spis ich sporządzać”, Bączkowicz, Prawo kanoniczne, t. 1, s. 533.

${ }^{26}$ Ks. Stanisław Librowski, organizator Archiwum Diecezjalnego we Włocławku stwierdził, że ,przed wojną 1939 r. na ogół rzadko przybywający do archiwum kwerendziści byli przyjmowani przez dyrektora tejże instytucji w kurii diecezjalnej albo w prywatnym jego mieszkaniu", S. Librowski, Sprawozdanie z działalności Archiwum Diecezjalnego we Włocławku 1945-1958, ABMK, $1(1959 / 1960)$ z. 1, s. 141.

${ }^{27}$ Pamiętnik IV Powszechnego Zjazdu Historyków Polskich, t. 2, s. 98, 142.

${ }^{28}$ K. Kaczmarczyk, Organizowanie archiwów diecezjalnych, w: Pamiętnik IV Powszechnego Zjazdu Historyków Polskich w Poznaniu 6-8 grudnia 1925 r., t. 1: Referaty, Lwów 1925, s. 1-7. 
wym diecezji łódzkiej ${ }^{29}$. Podniesienie sprawy nowoczesnej organizacji archiwów kościelnych na forum ogólnopolskim przyszło Kaczmarczykowi tym łatwiej, że na miesiąc przed zjazdem historyków zostało powołane do życia w Poznaniu pierwsze historyczne archiwum kościelne. Może nawet ten fakt spowodował wygłoszenie przez Kaczmarczyka wspomnianego referatu?

Po dyskusji nad referatem Kaczmarczyka na IV Powszechnym Zjeździe Historyków Polskich zaakceptowano propozycje zawarte w jego wystąpieniu, aby „1. Zwrócić się do Episkopatu polskiego, by idąc w ślady Ks. kardynała i prymasa Polski Dalbora, założyciela Archiwum Diecezjalnego w Poznaniu, dążył w porozumieniu z Ministerstwem W. R. i O. P. do tworzenia archiwów i bibliotek diecezjalnych i w ten sposób przyczynił się do badań nad historią Kościoła w Polsce. 2. Zwrócić się do Pana Ministra W. R. i O. P. o finansowe i moralne poparcie przez państwo Episkopatu katolickiego i duchowieństwa innych wyznań w akcji powyższej”"30. Apel do ministra był jak najbardziej uzasadniony, gdyż zorganizowanie nowoczesnego archiwum było sprawą kosztowną i nie wszystkich byłoby na to stać.

Do idei współpracy archiwistów pracujących w archiwach kościelnych i państwowych przywiązywano ogromną wagę. Jej przykładem było uporządkowanie przez Stanisława Zajączkowskiego archiwów konsystorskiego i kapitulnego we Lwowie ${ }^{31}$, Kazimierza Kaczmarczyka - archiwum cystersów w Mogile ${ }^{32}$ i archiwum paulinów na Jasnej Górze ${ }^{33}$. Idea współpracy zaowocowała zorganizowaniem w ramach VI Powszechnego Zjazdu Historyków Polskich w Wilnie (17-20 IX 1935 roku) ,konferencji w sprawie archiwów kościelnych i archiwaliów wyznaniowych w Polsce" (19 IX). Przewodniczył jej profesor Stanisław Zajączkowski, a udział w niej wzięli między innymi: Witold Suchodolski - naczelny dyrektor Archiwów Państwowych, ks. Adam Sawicki - kanclerz Kurii Archidiecezjalnej w Wilnie, ks. Czesław Falkowski - wykładowca historii Kościoła na Wydziale Teologicznym Uniwersytetu Stefana Batorego ${ }^{34}$. W konferencji uczestniczyło niezbyt liczne grono duchownych i świeckich, gdyż to dawało możliwość podjęcia konkretnych ustaleń. Referat wprowadzający wygłosiła Zofia OlszamowskaSkowrońska. Poświęciła go teoretycznym podstawom naukowej organizacji ar-

${ }^{29}$ „Wiadomości Diecezji Łódzkiej”, 7 (1927) s. 42-46.

${ }^{30}$ Pamiętnik IV Powszechnego Zjazdu Historyków Polskich, t. 2, s. 143. Por. Kaczmarczyk, Organizowanie archiwów diecezjalnych, s. 7.

${ }^{31}$ S. Zajączkowski, Archiwum Kapituly Lacińskiej we Lwowie, w: Archiwum Towarzystwa Naukowego we Lwowie, t. 2, Lwów 1923, s. 391-428; tenże, Archiwum Kapitulne we Lwowie, „Archeion”, t. 5 (1929) s. 31-36; tenże, Archiwum Archidiecezjalne obrzqdku tacińskiego we Lwowie, Lwów 1932; tenże, Inwentarz Archiwum Archidiecezjalnego obrzq̨dku łacińskiego we Lwowie sporzadzit [...] w latach1930-1931 [mps].

${ }^{32}$ K. Kaczmarczyk, K. Kowalski, Katalog Archiwum Opactwa Cystersów w Mogile, Kraków 1919.

${ }^{33}$ K. Kaczmarczyk, Archiwum O.O. Paulinów na Jasnej Górze w Częstochowie, „Archeion”, 6-7 (1930) s. 123-139. Być może to właśnie przez niego sporządzony katalog kartkowy posłużył do sporządzenia katalogu mikrofilmów Instytutu ABMK.

${ }^{34}$ Pamiętnik VI Powszechnego Zjazdu Historyków Polskich $w$ Wilnie 17-20 września 1935 r., t. 2: Protokoty, Lwów 1936, s. 261-262. 
chiwów kościelnych ${ }^{35}$. Rezultatem „szczerej i zasadniczej” dyskusji, która odbyła się po tym referacie było przyjęcie następującej uchwały: „konferencja w sprawie naukowej organizacji archiwów kościelnych i archiwaliów wyznaniowych w Polsce, odbyta w ramach VI powszechnego Zjazdu Historyków Polskich w Wilnie w dn. 19 IX 1935 r. - wzywa archiwistów kościelnych oraz archiwistów państwowych w Polsce do jak najszerszej kooperacji, a to za pomocą:

1) uczęszczania archiwistów kościelnych na Państwowy Kurs Archiwalny w Warszawie, prowincjonalne kursy archiwalne, praktykę w archiwach państwo$\mathrm{wych}^{36}$,

2) współpracy archiwistów kościelnych w czasopiśmie archiwalnym „Archeion" oraz utworzenia w jednym z czasopism kościelnych działu, poświęconego archiwistyce kościelnej,

3) współudziału w wydaniu inwentarza archiwaliów kościelnych, na razie na terenie b. Królestwa Kongresowego"37.

Jeden ze wspomnianych postulatów został zrealizowany już w 1935 roku. Redakcja „Ateneum Kapłańskiego”, doceniając wagę rozpowszechniania idei organizacji nowoczesnych archiwów kościelnych w Polsce, stworzyła nowy dział w tym czasopiśmie zatytułowany „Z archiwistyki kościelnej”. W skład zespołu redakcyjnego weszli: ks. Jan Kwolek ${ }^{38}$, Wincenty Łopaciński, Zofia Olszamowska-Skowrońska i ks. Stefan Wyszyński redaktor „Ateneum Kapłańskiego"39. Artykuł zatytułowany Archiwa - przeszłości skarbnice, autorstwa ks. Jana Kwolka z Przemyśla, zapowiadał program tego działu ${ }^{40}$. Do współpracy pozyskano najwybitniejszych archiwistów i historyków z grona świeckich i duchownych osób. Wśród tych, którzy opublikowali tam swoje prace ${ }^{41}$ znaleźli się: Aleksy Bachulski $^{42}$, Kazimierz Kaczmarczyk ${ }^{43}$, Wacław Tokarz ${ }^{44}$, Jadwiga Karwasińska ${ }^{45}$, Adam

${ }^{35}$ Z. Olszamowska-Skowrońska, Na marginesie VI Powszechnego Zjazdu Historyków Polskich w Wilnie 17-20 września 1935 r., AK, 21 (1935) 36, s. 529.

${ }^{36}$ Naczelny Dyrektor Archiwów Państwowych Witold Suchodolski umożliwił archiwistom kościelnym praktykę w archiwach państwowych, zachęcano do ukończenia watykańskiej Scuola Archivistica, zob. Olszamowska-Skowrońska, Na marginesie VI Powszechnego Zjazdu Historyków Polskich, s. 530.

${ }^{37}$ Tamże, s. 529.

${ }^{38}$ Oprócz artykułu programowego (Archiwa - przeszłości skarbnice), ks. Kwolek zamieścił także w omawianym czasopiśmie pracę o Archiwum Diecezjalnym w Przemyślu (Archiwum Diecezjalne przy Kurii Biskupiej ob. łac. w Przemyślu, AK, 22 (1936) t. 38, s. 514-526.

${ }^{39} \mathrm{AK}, 21$ (1935) t. 36, s. 524.

${ }^{40}$ Kwolek, Archiwa - przeszłości skarbnice, s. 524-528.

${ }^{41}$ Prace, które ukazały się w „Ateneum Kapłańskim”, omówił Kazimierz Konarski, Z archiwistyki kościelnej, s. 127-131.

42 A. Bachulski, Wskazówki bibliograficzne przy porzqdkowaniu archiwów parafialnych, AK, 21 (1935) t. 36, s. 530-533.

${ }^{43}$ K. Kaczmarczyk, Znaczenie archiwów klasztornych dla historii Kościoła i historii kultury duchowej i materialnej w Polsce, AK, 22 (1936) t. 37, s. 299-304.

${ }^{44} \mathrm{~W}$. Tokarz, W sprawie archiwów parafialnych $i$ klasztornych, AK, 22 (1936) t. 37, s. 304-305.

${ }^{45}$ J. Karwasińska, Przechowywanie dokumentów pergaminowych i papierowych, AK, 22 (1936) t. 38 , s. 95-104. 
Moraczewski ${ }^{46}$, ks. Józef Nowacki ${ }^{47}$, Aleksander Kossowski ${ }^{48}$, Władysław Adam$\operatorname{czyk}^{49}$, Mieczysław Niwiński ${ }^{50}$.

Pewne zalążki nowoczesnych archiwów diecezjalnych na ziemiach polskich można zaobserwować w wiekach wcześniejszych. Kazimierz Kaczmarczyk był zdania, że już w dawnej Rzeczypospolitej, w Wilnie powstało archiwum diecezjalne, które pod kierownictwem osobnego archiwisty diecezjalnego, gromadziło archiwalia parafialne. Zostało ono niestety w znacznej części rozproszone na skutek działań władz rosyjskich, które zarządziły zabranie wielu cennych dyplomów i rękopisów do biblioteki publicznej w Wilnie. W czasie pierwszej wojny światowej materiały te wywieziono w głąb Rosji ${ }^{51}$. W tym czasie rozważane było utworzenie archiwum diecezjalnego w Krakowie. Ta inicjatywa wypłynęła od ówczesnego ordynariusza tejże diecezji - bpa Adama Stefana Sapiehy. W Przemyślu zamierzał powołać do życia archiwum diecezjalne tamtejszy biskup Józef Sebastian Pelczar. Skończyło się na dobrych chęciach. Brak funduszów stanął na przeszkodzie stworzeniu takiej instytucji ${ }^{2}$. W niektórych kuriach diecezjalnych utworzono jednak urząd archiwariusza, co można ocenić jako zapowiedź dalszych działań na polu archiwalnym.

Pierwsze w II Rzeczypospolitej kościelne archiwum historyczne erygował w Poznaniu tamtejszy ordynariusz, prymas Edmund Dalbor. Od samego początku nosi ono nazwę Archiwum Archidiecezjalne, gdyż od wydania bulli De salute animarum w 1821 roku przez papieża Piusa VII Poznań jest stolicą archidiecezji. Dekret powołujący do życia to archiwum wydał ordynariusz poznański i prymas Polski Edmund Dalbor. Dekret zatwierdzający statut archiwum (opracowany przez ks. Edmunda Majkowskiego) został wydany z datą 13 października 1925 roku. Wszedł w życie 1 listopada 1925 roku. Prymas nie doczekał uroczystej inauguracji działalności archiwum, która nastąpiła w dniu 27 maja 1926 roku, gdyż zmarł 13 lutego 1926 roku. W 1925 roku zasób archiwum został umieszczony w gmachu dawnej Akademii Lubrańskiego, dostosowanym do nowych potrzeb. W poznańskiej kurii archidiecezjalnej utworzono urząd archiwariusza już w 1915 roku. Od 1 października tego roku objął go ks. Kamil Kantak. Jego następcą (od 1 VIII 1919 roku) został ks. Edmund Majkowski, organizator i pierwszy dyrektor archiwum. Od 1933 roku (do 1964 roku) kierował wspomnianym archiwum ks. Józef Nowacki.

Kolejne archiwa powstały w Przemyślu, Pelplinie, Płocku, Kielcach oraz Łodzi, gdzie funkcję archiwum pełniło początkowo Muzeum Diecezjalne.

${ }^{46}$ A. Moraczewski, Uwagi o przygotowaniu fachowym archiwistów, pracujacych nad aktami XIX i XX wieku, AK, 23 (1937) t. 39, s. 293-297.

${ }^{47}$ J. Nowacki, Archiwum Archidiecezjalne w Poznaniu, AK, 22 (1936) t. 38, s. 198-205.

${ }^{48}$ A. Kossowski, Archiwum Konsystorza Rz.-Katol. w Lublinie, AK, 23 (1937) t. 39, s. 290-293.

${ }^{49}$ W. Adamczyk, Archiwum Kapituly Katedralnej Lubelskiej, AK, 23 (1937) t. 40, s. 209-212.

${ }^{50}$ M. Niwiński, Archiwum konsystorza biskupiego w Tarnowie, AK, 23 (1937) t. 40, s. 203-209.

${ }^{51}$ Kaczmarczyk, Organizowanie archiwów diecezjalnych, s. 8. zob. także Pamiętnik IV Powszechnego Zjazdu Historyków Polskich, t. 2, s. 142.

${ }^{52}$ Kaczmarczyk, Organizowanie archiwów diecezjalnych, s. 5. 
Organizatorem Archiwum Diecezjalnego w Przemyślu był ks. Jan Kwolek, archiwariusz tamtejszej kurii diecezjalnej od 1918 roku. Opracował Statut organizacyjny dla archiwum, który zatwierdził ówczesny ordynariusz bp Anatol Nowak dekretem z dnia 15 października 1927 roku. Autorstwa ks. Kwolka, pierwszego dyrektora archiwum przemyskiego, był także Regulamin Pracowni Archiwum ${ }^{53}$. Archiwum zostało umieszczone w budynku kurii diecezjalnej.

Rok później po archiwum w Przemyślu powstało Archiwum Diecezji Chełmińskiej w Pelplinie. Erygował je 1 kwietnia 1928 roku bp Stanisław Wojciech Okoniewski. Pierwszym dyrektorem został ks. Paweł Panske. Funkcję tę sprawował do 1936 roku, kiedy to obowiązki dyrektora archiwum przejął ks. Antoni Liedtke $^{54}$. Stanisław Librowski niesłusznie przesunął datę powstania wspomnianego archiwum na okres powojenny ${ }^{55}$.

W Płocku wybudowano nowy gmach dla biblioteki seminaryjnej w latach 1925-1927. W nowo wybudowanym gmachu znalazły się pomieszczenia także dla archiwum diecezjalnego, które erygował bp Antoni Julian Nowowiejski. Dnia 15 lutego 1928 roku zatwierdził jego statut i regulamin. Uroczyste otwarcie archiwum nastapiło 23 kwietnia 1928 roku. Pierwszym dyrektorem był ks. Władysław Mąkowski.

Archiwum diecezjalne w Łodzi zamierzał erygować już w 1927 roku bp Kazimierz Tymieniecki. Nie doszło jednak do realizacji tego pomysłu. Dopiero bp Włodzimierz Jasiński erygował - ale już nie archiwum tylko Muzeum Diecezjalne. Razem z eksponatami muzealnymi zgromadzono materiały archiwalne. Opracowano statut i regulamin dla muzeum, które zostały opublikowane w „Wiadomościach Diecezjalnych Łódzkich" z 1938 roku. Ta decyzja władz diecezjalnych spotkała się z krytyką archiwistów. Wydawane w 1939 roku opracowania ks. Henryka Rybusa - pierwszego dyrektora archiwum - wskazują na to, że zbiory zostały już rozdzielone.

W Kielcach po 1917 roku został mianowany archiwariusz. Zaś archiwum historyczne zostało powołane do życia przez bpa Czesława Kaczmarka, który 28 marca 1939 roku zatwierdził jego statut i regulamin. Obydwa dokumenty zostały opublikowane w „Kieleckim Przeglądzie Diecezjalnym” ${ }^{\text {56 }}$. Do 1984 roku archiwum mieściło się w budynku seminarium duchownego.

Dodać trzeba, że istniejące w granicach powojennej Polski, Archiwum Archidiecezjalne we Wrocławiu w okresie międzywojennym znajdowało się poza jej granicami, na terenie państwa pruskiego. Jest to obecnie najstarsze i najbogatsze archiwum diecezjalne w Polsce. Jego reorganizacja dokonała się na skutek przeniesienia materiałów archiwalnych do wybudowanego w latach 1894-1896 (za rządów kardynała Jerzego Koppa) oddzielnego gmachu dla zbiorów diecezjalnych. Na pierwszym piętrze tego gmachu umieszczono zasób archiwum. Dnia

${ }^{53}$ J. Ataman, Ks. Jan Kwolek 1885-1958, ABMK, 1 (1959/1960) z. 1, s. 159-164.

${ }^{54}$ A. Nadolny, Archiwum Diecezjalne w Pelplinie. Zarys dziejów i informacja o zasobie, „Studia Pelplińskie", 21-22 (1990/1991) s. 263-316.

${ }^{55}$ S. Librowski, Archiwa Kościoła katolickiego w Polsce, w: Encyklopedia Katolicka, t. 1, Lublin 1973, kol. 879 .

${ }^{56}$ Erekcja Archiwum Diecezjalnego, „Kielecki Przegląd Diecezjalny”, 26 (1939) s. 162-169. 
1 lipca 1896 roku archiwum zostało otwarte. W 1929 roku, na mocy konkordatu zawartego między Stolicą Apostolską a Prusami, diecezja wrocławska została podniesiona do godności archidiecezji.

Do podstawowych osiagnięć kościelnej archiwistyki międzywojennej należałoby zaliczyć rozpoczęcie akcji reorganizacyjnej w archiwach kościelnych - czyli przekształcanie składnic akt w nowoczesne placówki gwarantujące wypełnianie podstawowych zadań nałożonych na tego typu instytucje (zabezpieczanie, trwałe przechowywanie, gromadzenie, opracowywanie i udostępnianie materiałów archiwalnych). Dotyczyło to głównie archiwów diecezjalnych, gdyż archiwa zakonne takich działań wówczas jeszcze nie podjęły. Celem zapoznania szerszego grona archiwistów, historyków, duchowieństwa diecezjalnego z problematyką dotyczącą funkcjonowania instytucji przechowujących kościelne materiały archiwalne rozpoczęto pracę popularyzacyjną. Poruszano te kwestie na zjazdach Zakładów Teologicznych, zjazdach historyków, a w ramach diecezji - na konferencjach dekanalnych. Ukazywało się wiele publikacji zarówno w czasopismach ogólnopolskich („Archein”, „Ateneum Kapłańskie”), jak i w miesięcznikach diecezjalnych. Na łamach tych ostatnich opublikowano kilka artykułów poświęconych kancelarii i registraturze parafialnej ${ }^{57}$.

W okresie międzywojennym powstało sześć nowoczesnych archiwów diecezjalnych. Rozpoczęto także prace nad samymi materiałami archiwalnymi. Uporządkowano i sporządzono inwentarze zasobów niektórych archiwów kościelnych, w tym kilku zakonnych. Prowadzono już wówczas akcję gromadzenia najstarszych akt parafialnych (głównie metryk) w zreorganizowanych archiwach diecezjalnych. Udostępniano także w ograniczonym zakresie kościelne materiały archiwalne do badań historycznych.

Poza osiagnięciami organizacyjnymi i popularyzatorskimi nie można nic powiedzieć o wkładzie archiwistów kościelnych w ustalenia teoretyczne. Wynikało to przede wszystkim z braku wśród duchownych osób, które miałyby przygotowanie w dziedzinie archiwistyki wynikające na przykład z ukończenia funkcjonujących wówczas na Zachodzie szkół archiwalnych. Żaden z polskich archiwistów kościelnych nie ukończył watykańskiej Scuola Archivistica ${ }^{58}$. Niektórzy z nich odbyli jedynie praktykę w archiwach państwowych. Jednym z nich był ks. Edmund Majkowski z Poznania, który celem zapoznania się z metodyką pracy archiwalnej ukończył kilkutygodniowy staż w Archiwum Akt Dawnych w Warszawie $^{59}$. Ksiądz Jan Kwolek zdawał sobie sprawę $\mathrm{z}$ niedostatecznego fachowego przygotowania archiwistów kościelnych, dlatego zachęcał, by archiwista kościelny, „choćby gdzieś studiował specjalnie historię, metodykę i nauki pomocnicze,

${ }^{57}$ Ksiegi parafialne, „Miesięcznik Pasterski Płocki”, 16 (1921) nr 7, s. 72-78; F. Mazurek, Archiwum, archiwalia i kancelaria parafialna, „Kielecki Przegląd Diecezjalny”, 26 (1939) nr 3, s. 143-149.

${ }^{58}$ Ksiądz Jan Kwolek, jeden z najbardziej znanych przedwojennych archiwistów kościelnych, też nie miał przygotowania archiwalnego. Ukończył rzymskie Gregorianum ze stopniem doktora prawa kanonicznego, zob. Ataman, Ks. Jan Kwolek, s. 159.

${ }^{59}$ L. Wilczyński, Archiwum Archidiecezjalne w Poznaniu w latach 1925-1939, „Archiwariusz. Biuletyn Archiwum Archidiecezjalnego w Poznaniu", 1 (2005) s. 15. 
choćby nawet przeszedł gdzieś kurs archiwistyki ogólnej" uzupełnił swoją edukację w dziedzinie archiwistyki drogą samokształcenia ${ }^{60}$. Najczęściej archiwariusze diecezjalni, oprócz powierzonego sobie zadania opieki nad archiwaliami, pełnili jednocześnie funkcje kierowników bibliotek seminaryjnych oraz muzeów diecezjalnych ${ }^{61}$, co w znacznym stopniu wpływało na sposób myślenia o kulturowych zbiorach Kościoła katolickiego. Stąd często w archiwum gromadzono - obok materiałów archiwalnych - także zbiory biblioteczne (inkunabuły, starodruki). W diecezji łódzkiej powołano do życia w 1938 roku tylko Muzeum Diecezjalne, które miało również pełnić rolę archiwum. Takie rozwiązanie spotkało się z krytyką Wincentego Łopacińskiego, którego opinię $\mathrm{w}$ tej sprawie warto przytoczyć $\mathrm{z}$ tego względu, iż pokazuje ona jak niepełna była znajomość w kręgach kościelnych zasad archiwistyki: „w omawianym Statucie Muzeum Diecezjalnego w Łodzi te dwa zgoła odrębne pojęcia Muzeum i Archiwum są pomieszane. Gorzej niż pomieszane, bo Archiwum jest wtopione w Muzeum. Autorzy Statutu nie zdawali sobie zgoła sprawy $\mathrm{z}$ tego, że ujęcie organizacyjnie $\mathrm{w}$ jedną instytucję dwu tak różnych rzeczy, jak Archiwum i Muzeum jest zupełną anomalią jest najzupełniej sprzeczne z ogólnie uznanymi zasadami archiwistyki. Nie ratuje sytuacji nawet stworzenie w Muzeum osobnego działu rękopisów [...], gdyż dział rękopisów, odpowiednio pojęty, jest właściwy w Bibliotece, nigdy w Muzeum"62. Pomysł władz diecezji łódzkiej nie był oryginalny na co wskazuje przykład Poznania. Tam już w 1898 r. otwarto Muzeum Archidiecezjalne, w którym „wydzielono specjalny dział dla zbiorów archiwalnych i bibliotecznych"63. Natomiast w statucie Archiwum Archidiecezjalnego w Poznaniu, powołanego do życia w 1925 r., wśród zadań nowej instytucji wymieniono między innymi ,utworzenie i utrzymywanie biblioteki z dziedziny teologii i filozofii chrześcijańskiej" ${ }^{64}$.

Energiczne działania na polu archiwistyki kościelnej, prowadzone w drugiej połowie lat trzydziestych, przerwał wybuch drugiej wojny światowej. Hieronim E. Wyczawski stwierdził, iż ,pełniejsza realizacja międzywojennych zamierzeń odnośnie do archiwów kościelnych nastapiła jednak dopiero po drugiej wojnie światowej, gdy jej katastrofalne dla archiwów skutki dowiodły aż nadto, iż nie można już zwlekać z zabezpieczeniem ocalałych z pożogi wojennej zbiorów i udostępnieniem ich nauce" ${ }^{65}$. W drugiej połowie lat pięćdziesiątych dwudziestego wieku zadania te przejął Ośrodek (od 2006 roku - Instytut) Archiwów, Bibliotek i Muzeów Kościelnych. Propagowano tę ideę na łamach jego organu - półrocznika „Archiwa, Biblioteki i Muzea Kościelne”. I chociaż dopiero po drugiej wojnie światowej zostały zintensyfikowane działania na polu organizowania hi-

\footnotetext{
${ }^{60}$ Kwolek, Naukowa organizacja archiwów diecezjalnych, s. 23.

${ }^{61} \mathrm{~Np}$. ks. Edmund Majkowski, archiwariusz poznański był jednocześnie bibliotekarzem seminaryjnym i kierownikiem Muzeum Archidiecezjalnego (Wilczyński, Archiwum Archidiecezjalne w Poznaniu w latach 1925-1939, s. 15).

${ }^{62}$ W. Łopaciński, Statut i regulaminy Muzeum Diecezjalnego w Lodzi, „Archeion”, 15 (19371938) s. 133.

${ }^{63}$ Wilczyński, Archiwum Archidiecezjalne w Poznaniu w latach 1925-1939, s. 14.

${ }^{64}$ Tamże, s. 18.

${ }^{65}$ Wyczawski, Polskie archiwa kościelne, s. 92-93.
} 
storycznych archiwów kościelnych, to jednak założenia tej akcji zostały wypracowane już w okresie międzywojennym, a lata powojenne były początkowo tylko kontynuacją procesu zapoczątkowanego po powstaniu w 1918 roku niepodległego państwa polskiego.

\section{DIE ARCHIVE DER KATHOLISCHEN KIRCHE IN DER ZWEITEN REPUBLIK POLEN}

\section{Zusammenfassung}

Die Zeit der Zweiten Republik ist außerordentlich wichtig für die Reorganisation der kirchlichen Archive. Erst damals begann man diese als wissenschaftliche Institutionen und als Arbeitswerkstatt für Historiker wahrzunehmen. Initiiert wurde die Erabeitung moderner Formen ihres Funktionierens. Dieser Wandlungsprozess vollzog sich in der Zusammenarbeit von geistlichen und weltlichen Archivaren und Historikern. Besondere Verdienste für die Propagierung der Idee, moderne kirchliche Archive zu schaffen, erwarben sich Kazimierz Kaczmarczyk (der Direktor des Staatsarchivs in Poznań) und P. Jan Kwolek (der Direktor des Diözesanmuseums in Przemyśl). Grundlage der Aktivitäten zur Reformierung der kirchlichen Archive war, dass ihnen der Status selbständiger Institutionen im Rahmen der Diözesen oder der Orden und Ordensgemeinschaften zuerkannt wurde. Die ersten historischen Archive der polnischen Kirche in der Zwischenkriegszeit entstanden in den Diözesen Poznań, Przemyśl, Płock, Chełmno (in Pelplin), Łódź und Kielce. 